INDEPENDENT JOURNAL OF MANAGEMENT \& PRODUCTION (IJM\&P)

http://www.ijmp.jor.br $\quad$ v. 11, n. 5, Special Edition IFLOG 2019 -September 2020 ISSN: 2236-269X

DOI: 10.14807/ijmp.v11i5.1296

\title{
DISCRETE SIMULATION APPLIED TO QUEUE MANAGEMENT IN A
} SUPERMARKET

\author{
Jefferson Vasconcelos Pereira Junior \\ Instituto Federal de São Paulo - Campus Suzano, Brazil \\ E-mail: jeffersonvazconcellos@gmail.com \\ Adriano Maniçoba da Silva \\ Instituto Federal de São Paulo - Campus Suzano, Brazil \\ E-mail: adrianoms@ifsp.edu.br \\ Diego Galileu de Moraes \\ Instituto Federal de São Paulo - Campus Suzano, Brazil \\ E-mail: professordi@gmail.com
}

Submission: 2/29/2020

Revision:3/3/2020

Accept:3/6/2020

\section{ABSTRACT}

This research presents a case study related to the management of queues in a supermarket and the problems found in the organization of this process. In order to reduce the time that customers remain in the checkout lines, an analysis of the environment (supermarket) was carried out virtually through the discrete simulation technique, linked to the Arena software. This technique is classified as quantitative because it makes it possible to measure entities and predict the action of the environment in a way that mimics the reality of the queues at the site. Through the simulated scenario, it was possible to identify the flaws in the process and the cause of the queuing. Through the results of the simulation, it was observed that the average length of stay in the queue would be reduced by $88.23 \%$ if it contemplates the inclusion of 2 to 3 employees to perform the service. Note that the application of this technique is favorable for problem solving and decisionmaking, as it reduces the time that customers spend in the queue and optimizes the financial investments allocated in this area.

Keywords: Discrete simulation; Queue management; Arena software 
DOI: $10.14807 /$ ijmp.v11i5.1296

\section{INTRODUCTION}

In a world where customer satisfaction has been a predominant factor in determining the quality of an establishment, it is of fundamental importance to offer quality services, and in addition, to have better products and services in order to attract more customers.

With this perspective, it is observed that the market competitiveness can be defined as a condition that differentiates the company in relation to its competitors. Previous studies state that, in practical terms, this competitiveness are the characteristics that drive the customer's action to buy a product $\mathrm{X}$, and the fact that it is advantageous to buy it at establishment $\mathrm{Y}$ (COUTINHO; FERRAZ, 1995).

Even with technological advances and the automation of various processes in supermarket service, for many consumers the queues at checkout are still considered their worst time in the store. According to Marins (2011), when it comes to providing services, customer dissatisfaction leads to loss of business. This scenario reflects the need and relevance to manage queues, in order to leverage business.

Based on the presented scenario, it is understood that when there are failures in the queuing process, making them long-lasting, causing discomfort, dissatisfaction and costumer loss. Within the current market reality, the customer invariably does not allow errors, delays or excuses. There is also a high demand with regard to quality and there is little room for untested attempts (PESSANHA et al., 2011). Soon there is a logical research field in this environment to contribute to the evolution of the business.

It is generally observed that according to Prado (2014), from the customer's point of view, the ideal would be to design systems for the absence of queues, and if this were really possible, there would be no dissatisfied customers. However, this process cannot be eliminated, but improved. According to Vergara et al. (2019), it is essential to understand that queues are part of our daily lives, being present in banks, bakeries, pharmacies and supermarkets. Due to the constant presence of queues in human life, it is possible to identify the need to manage this process.

This research has as general objective to apply the discrete simulation in the process of management of cash queues of a supermarket, in order to optimize the time of permanence of customers in the queue, leaving them satisfied and attracting more customers thus contributing to the evolution of the business. 
Through simulation it is possible to make deductions about the behavior of environments and systems, through experiments (PEÑA; SANTOS, 2018). That is, a way to decrease and or eliminate errors, being possible to test changes and improvements, in a virtual way, without changing the reality of the simulated environment, being a powerful tool in decision-making. The survey also has the specific objective of optimizing the time spent by customers at the checkout line; present the time of use of the attendant and optimize the total time of the cashier.

\section{LITERATURE REVIEW}

Based on the understanding that simulating means making it seem real, or an imitation close to reality, Moreira (2007), states that, we are all somewhat used to simulation, through electronic games, cinema, theaters, war-simulated scenarios by the armed forces and others.

According to Chwif and Medina (2014), the simulation is composed of a computational model, whose variables present the same dynamic and stochastic model as the real system it represents. In addition, simulation is a method of solving a problem using the analysis of a model that characterizes the behavior of the system using a computer (PRADO, 2014).

Presenting the concept of simulation, Silva et al. (2010), complement showing that the method means to reproduce the functioning of a system, with the aid of a model, which allows it to test some hypotheses about the value of controlled variables. In practice, simulation often involves the use of computers (MOREIRA, 2007).

Simulation models are, therefore, a powerful tool for forecasting the operation of operations under different circumstances (MIRANDA et al., 2017).

Composing a sophisticated and easily applicable tool, computer simulation has been used more than ever for the development and observation of environments (MIYAGI, 2006).

Counteracting the disadvantages of using the simulation, where it is complex and difficult to interpret the simulation data (SANTOS, 1999, p. 1-2). In the perspective of Freitas Filho (2008), the technique and its basic concepts are in general easy to understand and justifiable for both users and managers who make the decision to apply them.

During the simulation creation process, the difficulty of collecting data may still arise, due to the lack of a system, or due to the deficit in the collection of information. It is observed that in these cases heuristic procedures are used (SANTOS; DANTAS, 2018). 
DOI: 10.14807/ijmp.v11i5.1296

Second, Chwif and Medina (2014), a complementary fact about the simulation is that it cannot be considered a mathematical model, although it is possible to use mathematical formulas, there is no closed analytical expression, or a set of equations that when provided the input values provide the results of system behavior.

It is also important to emphasize that the simulation does not replace the work of human analysis, but linked to the complex work of analysis, it is considered a powerful tool, capable of providing results for a more elaborate analysis regarding the dynamics of the system. In this way, the simulation allows a deeper and more comprehensive interpretation of the studied system (DUARTE, 2003; DASSAN et al., 2016; COSTA et al., 2017; CLEMENTINO et al., 2018).

According to the definitions presented, these must be transformed into logical or mathematical associations constituted in computational models in order to understand and evaluate the behavior of the current system and, later, modifying its input variables, obtaining specific answers that may or may not meet the requirements. objectives of the model.

Starting from the point where the simulation is classified as a powerful and efficient technique, Silva et al. (2010) also state that the simulation is applied in situations where the experiment in the real situation is very expensive or difficult. The use of the computer simulation technique enables a more comprehensive analysis, from different perspectives and not only that of cost reduction (OLIVEIRA et al., 2009).

\subsection{Discrete Simulation Method}

Discrete event simulation is one in which changes in the state of the system occur instantly at random points in time as a result of the occurrence of discrete events. For example, in a queuing system in which the state of the system is the number of customers, the discrete events that change that state are the arrival and departure of a customer as a result of completing this service. Most simulation applications are simulation by discrete events (HILLIER; LIEBERMAN, 2012; CORDEIRO et al., 2017; CAMPOS; ENCARNAÇÃO; SILVA, 2019; CARVALHO et al., 2020).

When classified as discrete, or discrete models, the variables are not changed over a period of time, the future changes that can occur are applied at well-defined points, and can be termed by the time the event occurred (FREITAS FILHO, 2008).

Important points to be classified are the variations that occur, which can be discrete or continuous. 
DOI: 10.14807/ijmp.v11i5.1296

The discrete simulation determined by events, is based on a series of events organized by table. It uses probabilistic functions and can model more complex systems. Its dynamics occur through a sequence of separate (discrete) events in time (VIEIRA, 2006; SILVA et al., 2018; GOMES et al., 2019; MORAES; FERREIRA; SILVA, 2019).

According to Marcelino et al. (2018), the simulation of discrete events has dependent variables that change at different times, thus forming events. In other words, the state of the simulated system changes at the time of the events. Discrete event simulations model part of the flow of a manufacturing process. The partial flow is divided into a series of events.

Miyagi (2006) reinforces the idea that discrete simulation is an appropriate technique for analyzing systems whose changes in variables occur in a small way during the occurrence of events. The simulation models are not examined by analytical methods but evaluated by numerical methods. That is, analytical methods employ deductive / mathematical thinking to solve a model. Numerical methods are those that employ computational procedures to perform mathematical models. Therefore, when the simulation is properly applied, hypothetical data is generated, which were based on the assumed estimates.

Any simulation of systems that contains random variables generates random results. For Freitas Filho (2008), as these values can present great variability, which means it is necessary to make appropriate analyzes when one wants to make any kind of inference about the simulation results. These analyzes are made in the right number of replications, in how to interpret the differences obtained in each replication, in the duration of the simulation round, among others.

The applications of computer simulation techniques according to Banks et al. (2010) can only address discrete events, when the analysis involves problems of a dynamic nature, but which change their states at specific times of time. Or they can deal with continuous events, which change their states continuously over time.

In summary, a discreet approach the passage of time is discretely noticed, in moments and unnoticed this time is an event. Such events must occur in a chronological order, that is, the events with the lowest associated time first (SASAKI, 2007 p.19). Chwif and Medina (2014), exemplify the discrete simulation in figure 1. 


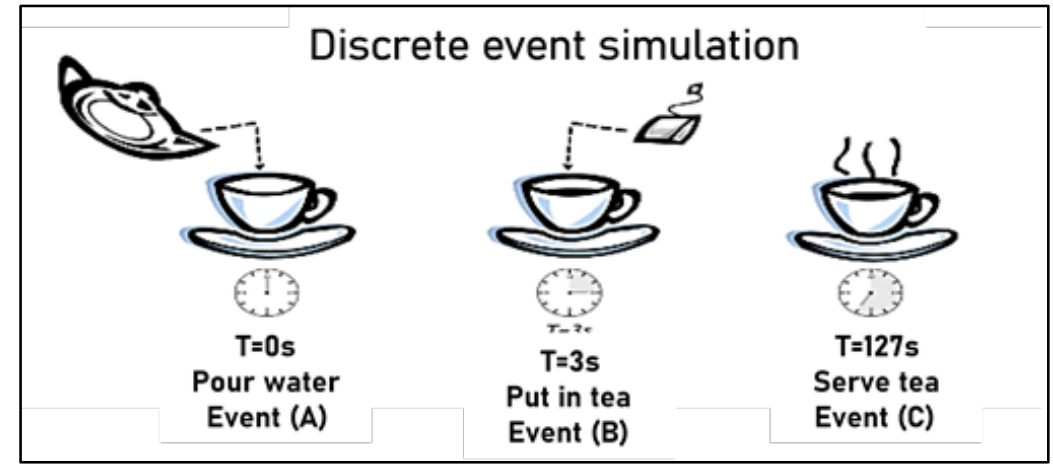

Figure 1: Discrete simulation

Source: Chwif and Medina (2014 p. 10)

\subsection{Simulation Software}

There are many software and platforms on which the simulation technique can be applied. Due to the diversity of cases to be solved by this method, according to Prado (2014), among the most used software are Arena, Promodel, Automod, Taylor, GPSS, GASP, SIMSCRIPT, SIMAN, etc.

The ARENA ${ }^{\circledR}$ software, which, according to Antunes and Santos (2019), emerged in 1993 from the unification and improvement of two simulation systems, aside from allowing the construction of a model, ARENA ${ }^{\circledR}$ has a useful tool: Input Analyzer, which determines the best probabilistic distribution for real data and results analyzer, which analyzes the data computed during the simulation (PRADO, 2014).

Also according to Prado (2014), Arena is an integrated graphic simulation environment, which has all the resources of process modeling, design and animation, statistical analysis and results analysis. Recognized as "The most innovative simulation software", combining features of a simulation language with the ease of use of a simulator, in an integrated graphic environment.

To further understand the data, the distribution sample analysis is performed, the distribution is a probability theory that serves to analyze the stochastic behavior of the variables under analysis (FREITAS FILHO, 2008).

Freitas Filho (2008) reinforces that the Arena software performs several static models, thus showing the probability distributions of the stochastic behavior of the simulation variable, the Poisson distribution, is one of the most used for queuing theory, as it models the numbers of occurrences discrete that they can assume along the variables.

In a complementary way, Arena still has a fermentation of adhesion test called Chisquare, in which it measures and evaluates the deviation between the distribution. It is 
DOI: 10.14807/ijmp.v11i5.1296

important to note that the application of Chi-square is not recommended for small samples (FREITAS FILHO, 2008).

There is also the formula of Harrel et al. (2004), for checking the confidence level, as shown in Figure 2.

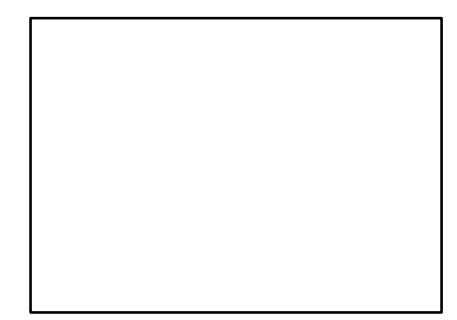

Figure 2: Calculation of confidence level Source: Harrel et al. (2004, p. 228)

Where:

n'= the number of replications $\mathrm{s}$

$\mathbf{s}=$ the standard deviation of the collected data $\mathrm{x}$

$\overline{\boldsymbol{x}}=$ the average of the collected data re

$\mathbf{r e}=$ the percentage error defined by the user

\section{METHODOLOGY}

According to Silva and Menezes (2005), research is a set of actions, proposed to find the solution to a problem. In order to better understand and solve the problem in addition to the theoretical study, which covers discrete simulation, queue management, and environmental analysis.

According to Diehl (2004), the choice of the research analysis method will be due to the nature of the problem, as well as according to the level of depth.

Based on this understanding, the choice of the research method for the case was quantitative research through the use of quantification, both in the collection and treatment of information, using statistical techniques, aiming at results that avoid possible distortions of analysis and interpretation, enabling greater safety margin (DIEHL, 2004).

In a complementary way, the case study protocol was used in the research, according to Yin (2015); the case study protocol is a way to increase the reliability of the research. Following the protocol, the case study must be presented in 4 divisions or parts. 
DOI: 10.14807/ijmp.v11i5.1296

\subsection{Part A: Overview of the Case Study}

The case study aims to optimize the time spent by customers during cash flow in a supermarket, with this studying the management of queues through discrete simulation.

The case study takes place in a supermarket in which it has been operating for 8 years. In its beginning, the establishment only resold products related to fruit and vegetables (fruits, vegetables, spices, grains, seeds, eggs, etc.). By offering quality food to its consumers and in a timely manner, customers began to make purchases more frequently, which led to an increase in inventory to meet the demand of fixed customers and new customers; with that, the owners identified the need to offer new products in order to better serve their customers and attract new consumers.

Currently the supermarket offers its consumers fresh produce, cleaning items, handicraft items, treats, breads, cold cuts, meats, sausages, items for minor repairs, drinks etc. With a larger and better collection of products, today the market serves its fixed customers, also attracts customers from other regions. However, with the increase in consumers, it is possible to observe that the supermarket has grown rapidly, but in disarray, that is, it has grown in customers and products and has not developed the structure to efficiently serve its customers; this way their consumers are uncomfortable, dissatisfied and some even stop being customers.

\subsection{Part B: Data Collection Procedure}

Data collection planning:

- Step 1: Interview the owner of the establishment in order to better understand the operation of the establishment.

- Step 2: Data collection for the simulation.

\subsection{Part C: Data Collection}

In this process, the action of data collection will be described in detail, through interviews and observation.

\subsection{Step 1: Interview}

The interview is a procedure for collecting information on a given scientific topic. According to Yin (2015), the interview is one of the most important data sources. The Interview cited in this step is available in appendix 2 of this work. Only the initial conclusion will be 
DOI: 10.14807/ijmp.v11i5.1296

presented here, which was used to start the simulation data collection, which will be cited later along with technical data from it.

- Date: September 12, 2018

- Place of interview: Supermarket

- Interviewee: Owner of the establishment

- Duration: 30 min

In summary, it was found in an interview with the owner that the flow of people is greater on Saturday mornings, as there is a variety of fresh and natural products available for consumption. Due to this fact, long queues are created.

\subsection{Step 2: Simulation Data Collection}

Based on the information obtained in the interview, and on the study presented regarding the discrete simulation as well as the queuing theory, the initial data were acquired manually, and through observations of the supermarket scenario, according to Zanelli (2002) the technique of observation places the researcher within the studied context, in order to understand the functioning of the structure under analysis.

Soon the observation followed the following parameters:

- Date: September 15, 2018,

- Time of data collection: 07:00 to 11:00.

- Place: Supermarket - cashier area

Entries and exits were observed, thus generating 147 entities to perform the simulation. The data collected is in Appendix 1 of this work.

Among the simulation methods presented, the one chosen was the simulation by discrete events, in which the state of the simulated system changes at the time of the events. This means it has an approach with random data, based on real data collection making the visualization of a scenario (in this case queues being generated and solved) possible virtually, which generates results that approximate the reality of the establishment.

Based on the simulation technique, software is required for its application. The program used for the queue simulation in this case is the Arena software, which has two useful tools: 
DOI: 10.14807/ijmp.v11i5.1296

Input Analyzer, which determines the best probabilistic distribution for the real data and results analyzer, which analyzes the computed data during the simulation (PRADO, 2014).

\section{RESULTS}

The collected data were inserted in a control spreadsheet, and later inserted in the Arena software. This section was divided into two parts, data adherence test and simulation results.

From the information collected manually on site, the data was sequentially inserted into LibreOffice calc, to start the process called frequency, distribution and data adherence test. Such action generated Table 1.

Table 1: Frequency of service time

\begin{tabular}{cc}
\hline No. of intervals & $\mathbf{1 2}$ \\
\hline Tamanho gives a show & 147 \\
\hline Minimum & 1 \\
\hline Maximum & 16 \\
\hline Amplitude & 1,25 \\
\hline Half & 6,69 \\
\hline Bypass Padrão & 2,65 \\
\hline Number of simulations for 95\% reliability & 266,53 \\
\hline
\end{tabular}

Source: Prepared by the study authors

With table 1 , it is possible to observe the distribution of data on service time in the supermarket, showing that to obtain 95\% reliability, a simulation with 266 entities would be necessary.

Table 2: Frequency of the service time sample

\begin{tabular}{ccccc}
\hline Classes & Interval & Frequency & $\mathbf{\%}$ & $\sum \%$ \\
\hline $\mathbf{1}$ & 0 & 0 & $0 \%$ & $0 \%$ \\
\hline $\mathbf{2}$ & 1,25 & 3 & $2 \%$ & $2 \%$ \\
\hline $\mathbf{3}$ & 2,5 & 5 & $3 \%$ & $5 \%$ \\
\hline $\mathbf{4}$ & 3,75 & 5 & $3 \%$ & $9 \%$ \\
\hline $\mathbf{5}$ & 5 & 37 & $25 \%$ & $34 \%$ \\
\hline $\mathbf{6}$ & 6,25 & 25 & $17 \%$ & $51 \%$ \\
\hline $\mathbf{7}$ & 7,5 & 17 & $12 \%$ & $63 \%$ \\
\hline $\mathbf{9}$ & 8,75 & 17 & $12 \%$ & $74 \%$ \\
\hline $\mathbf{1 0}$ & 10 & 30 & $20 \%$ & $95 \%$ \\
\hline $\mathbf{1 1}$ & 11,25 & 2 & $1 \%$ & $96 \%$ \\
\hline \multicolumn{6}{|c}{} & 12,5 & 3 & $2 \%$ & $98 \%$ \\
\hline & 13,75 & 3 & $2 \%$ & $100 \%$ \\
\hline
\end{tabular}

Table 2 shows that $63 \%$ of customers stay more than 5 minutes in the entire queuing process, it is also observed that $95 \%$ of customers stay up to 10 minutes in the total service process in the supermarket, thus generating customer dissatisfaction when waiting. 
DOI: 10.14807/ijmp.v11i5.1296

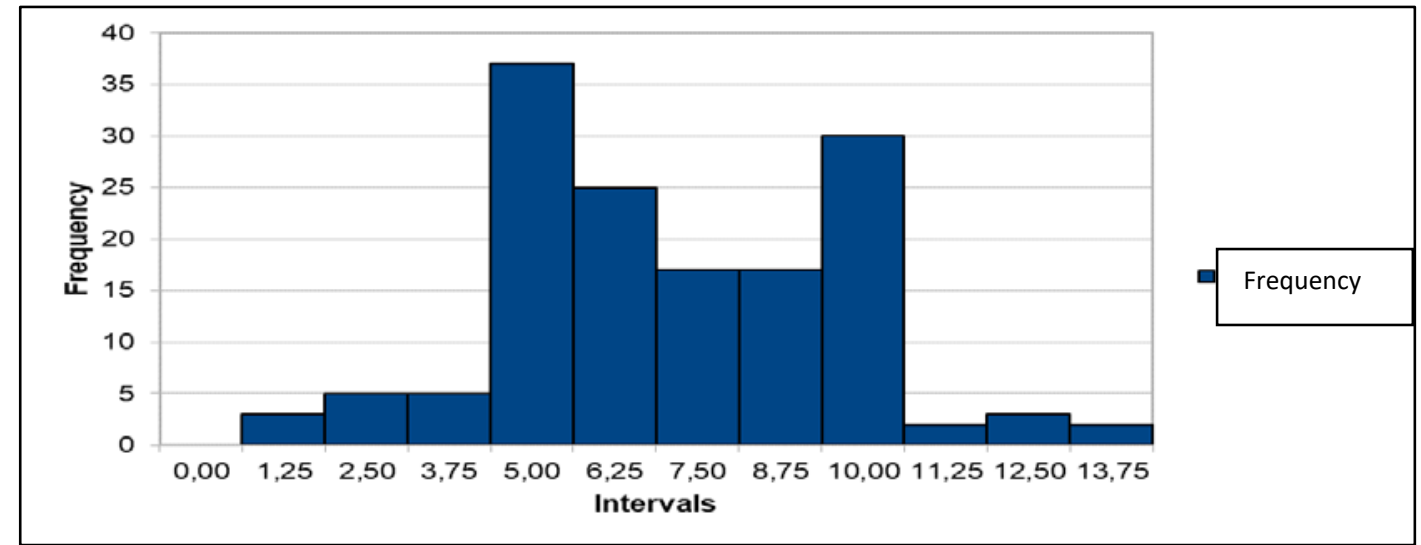

Graph 1: Histogram of the sample of service time at libre office Source: Prepared by the study authors

Graph 1 represents a Poisson distribution, which means that the distribution is applicable when the number of possible discrete occurrences is much greater than the average number of occurrences in a given interval of time or space.

Table 3: Test of sample of service time

\begin{tabular}{cc}
\hline \multicolumn{2}{c}{ Teste do Chi-Quadrado } \\
\hline No. of intervals & 8 \\
\hline Degrees of freedom & 6 \\
\hline Statistical test & 2,81 \\
\hline Corresponding p-value & 0,75 \\
\hline Source: Prepared by the study authors &
\end{tabular}

To test the adherence of the service time, the data was inserted in the Arena software, table 3 shows the test of the service time sample, giving a p-value of 0.75 which is higher than 0.05, showing that the data collection is adhering to a Poisson distribution.

According to the results obtained through the distributions, the application of this data in the Arena software was carried out, thus generating the simulation scenarios to find the ideal number of attendants to supply the customer demand, eliminating in turn the formation of unnecessary queues.

The layout of the simulated scenario (supermarket) consists of: Bakery, produce, household items, stationery, cleaning and hygiene products, drinks, and grains and cereals, as shown in figure 3. 
DOI: 10.14807/ijmp.v11i5.1296

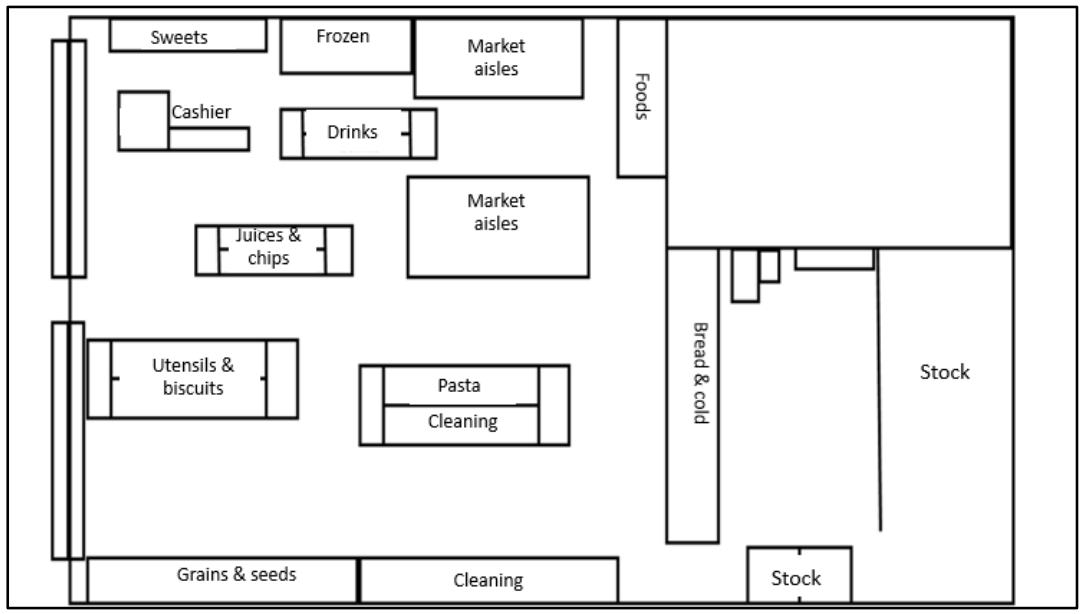

Figure 3: Supermarket layout

Source: Prepared by the study authors

As part of the process, a flowchart was created in the Arena software, exemplifying the queuing system at the supermarket, as shown in Figure 4, as a model for the operation of the simulation.

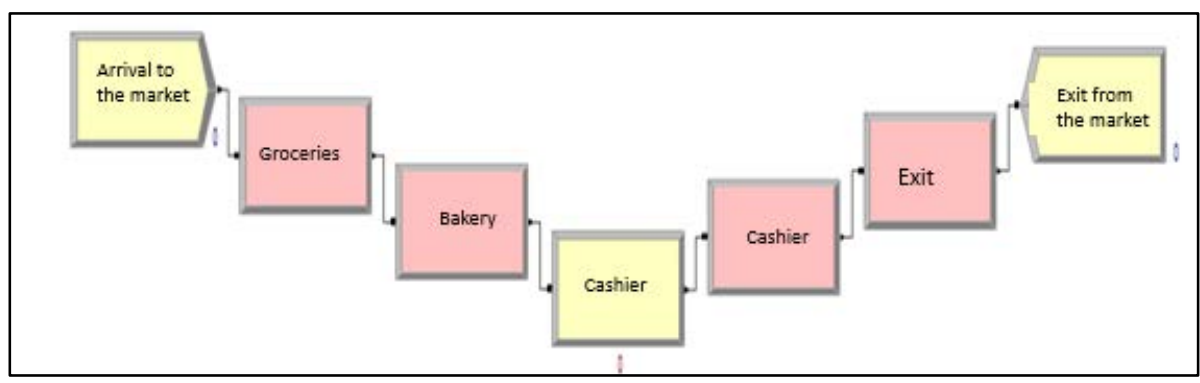

Figure 4: Flowchart in the Arena

Source: Prepared by the study authors

Figure 5 represents the layout of the supermarket linked to the flowchart in which the simulation was applied; in order to illustrate the process.

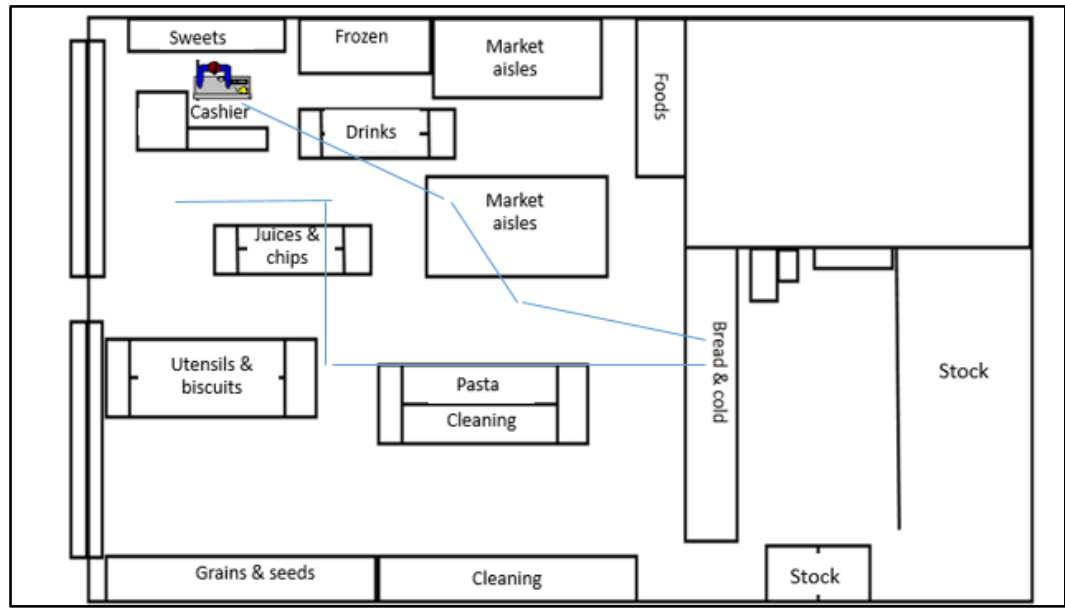

Figure 5: Arena layout / Simulate function

Source: Prepared by the study authors 
DOI: 10.14807/ijmp.v11i5.1296

It is observed that figure 6 has the representation of entities in motion during the simulation, this figure aims to illustrate / imitate the functioning of the queue in the supermarket, in order to propose an understanding of the process of simulating.

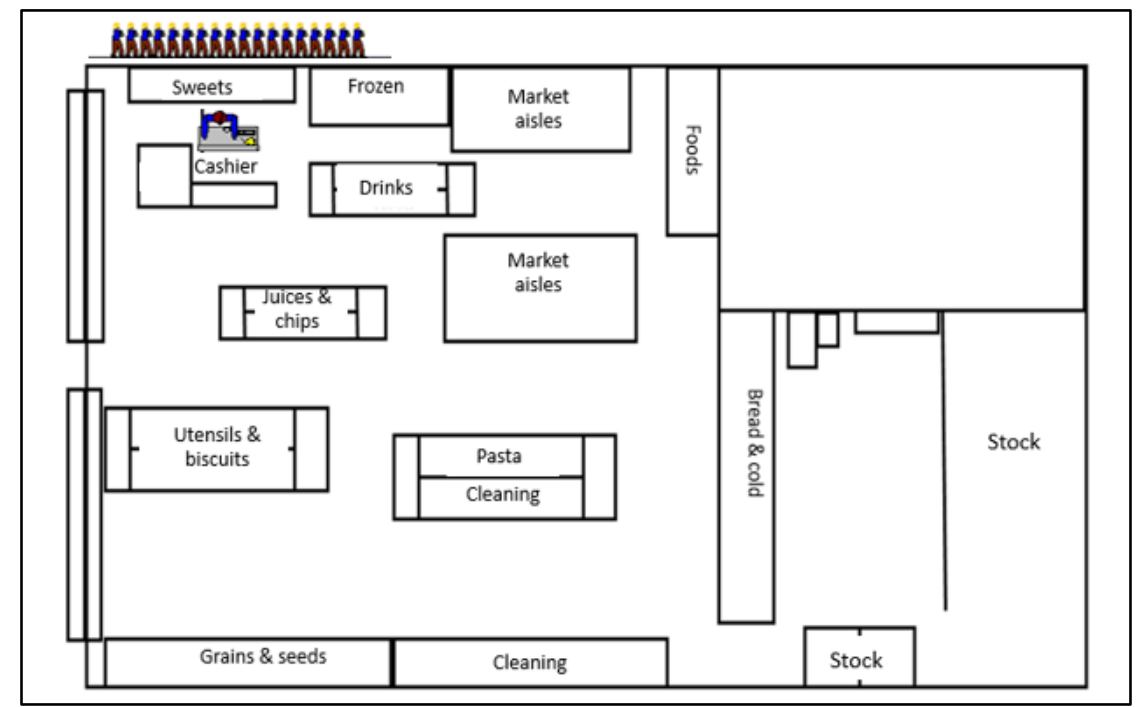

Figure 6: Simulation without execution

Source: Prepared by the study authors

Table 4 shows the replications of the simulation, bringing replications from 1 to 10 attendants, thus exposing the average time that each entity remains in the queue, the average size of the queue, the percentage of use of each attendant and the total entity that is processes in each simulation. This information seeks to find an optimal solution to the problem of queuing at the market.

Table 4: Simulations in the Arena software

\begin{tabular}{ccccc}
\hline $\begin{array}{c}\text { Number of } \\
\text { Attendant }\end{array}$ & $\begin{array}{c}\text { Average } \\
\text { queue } \\
\text { time }\end{array}$ & $\begin{array}{c}\text { Average } \\
\text { queue size }\end{array}$ & $\begin{array}{c}\text { Average } \\
\text { attendant } \\
\text { usage }\end{array}$ & $\begin{array}{c}\text { Total number of } \\
\text { entities processed }\end{array}$ \\
\hline $\mathbf{1}$ & 2,64 & 57,27 & $100 \%$ & 73 \\
\hline $\mathbf{2}$ & 1,02 & 27,21 & $98,50 \%$ & 137 \\
\hline $\mathbf{3}$ & 0,12 & 3,35 & $93,33 \%$ & 198 \\
\hline $\mathbf{4}$ & 0,02 & 0,64 & $75,50 \%$ & 213 \\
\hline $\mathbf{5}$ & 0,01 & 0,24 & $63,40 \%$ & 221 \\
\hline $\mathbf{6}$ & 0 & 0,06 & $52,12 \%$ & 221 \\
\hline $\mathbf{7}$ & 0 & 0,01 & $44,57 \%$ & 221 \\
\hline $\mathbf{8}$ & 0 & 0 & $39,12 \%$ & 221 \\
\hline $\mathbf{9}$ & 0 & 0 & $34,77 \%$ & \\
\hline
\end{tabular}

It is observed that the simulation with an attendant does not meet the need for service attendance, but with 2 or 3 attendants the volume of entities in the study is attended effectively by optimizing time.

Table 5: \% reduction in service time in simulations 
DOI: 10.14807/ijmp.v11i5.1296

\begin{tabular}{ccccc}
\hline $\begin{array}{l}\text { Number of } \\
\text { Attendant }\end{array}$ & $\begin{array}{c}\text { Average } \\
\text { queue time }\end{array}$ & $\begin{array}{c}\text { Average queue } \\
\text { size }\end{array}$ & $\begin{array}{c}\text { Average } \\
\text { attendant usage }\end{array}$ & $\begin{array}{c}\text { Total number of } \\
\text { entities processed }\end{array}$ \\
\hline $\mathbf{1 - 2}$ & $61,36 \%$ & $52,48 \%$ & $1,50 \%$ & $87,67 \%$ \\
\hline $\mathbf{2}-\mathbf{3}$ & $88,23 \%$ & $87,68 \%$ & $5,17 \%$ & $44,52 \%$ \\
\hline $\mathbf{3}-\mathbf{4}$ & $83,33 \%$ & $80,89 \%$ & $17,83 \%$ & $7,57 \%$ \\
\hline $\mathbf{4 - 5}$ & $50 \%$ & $62,5 \%$ & $12,10 \%$ & $3,75 \%$ \\
\hline $\mathbf{5 - 6}$ & $0 \%$ & $75 \%$ & $11,28 \%$ & $0 \%$ \\
\hline $\mathbf{6 - 7}$ & $0 \%$ & $83,33 \%$ & $7,55 \%$ & $0 \%$ \\
\hline $\mathbf{7 - 8}$ & $0 \%$ & $0 \%$ & $5,45 \%$ & $0 \%$ \\
\hline $\mathbf{8}-\mathbf{9}$ & $0 \%$ & $0 \%$ & $4,35 \%$ & $0 \%$ \\
\hline $\mathbf{9 - 1 0}$ & $0 \%$ & $0 \%$ & $3,47 \%$ & $0 \%$ \\
\hline
\end{tabular}

Source: Prepared by the study authors

Table 5 highlights the reduction of the aspects studied in the simulation. It is observed that with 2 or 3 attendants there is a reduction in the average queue time of $88.23 \%$, which results in more agility and less time in the queue to be attended. It is also noted that the average queue size was reduced by $87.68 \%$. This action had an impact on the reduction in the average use of the attendant, reducing $5.17 \%$. It is important to note that the table also shows an increase of $44.52 \%$ in the total field of processed entities.

\section{DISCUSSION}

With the processing of the service time data inserted in the Arena, precisely in the step Input Analyzer, a Poisson distribution was obtained, that is, a discrete distribution of the data. Prado (2014), confirms the accuracy of this process, with the Input Analyzer capable of presenting the best data distribution.

It is observed that $95 \%$ of customers stay more than ten minutes in the checkout line and this causes discomfort and dissatisfaction for them, which can interfere with the return and loyalty of customers. Marins (2011), states that the quality of service provision is directly linked to customer retention or loss.

It is important to note that the layout of the simulated environment was not physically changed during the simulation. Moreira (2007) mentions this characteristic of the simulation method.

A layout was created reproducing / imitating the real structure of the supermarket, in order to reproduce the functioning of the queue, that is, the movement of entities Silva et al. (2010). This stage is exposed in results with the objective of illustrating the simulation process.

In order to solve the problem of permanence of customers in the queues, where each customer spends 10 minutes in this process; the simulation was performed with the attendants 
DOI: 10.14807/ijmp.v11i5.1296

variable from 1 to 10 , with that it was possible to observe the average time in the queue, average size of the queue, average use of the attendant and total number of entities processed which resulted in the identification of the best solution to be applied in the environment, that is, making available two or three attendants that will reduce the average length of time in line by 88.23\% (PRADO, 2014).

The concept of discrete simulation applied to the case made it possible to understand the simulated system, affirming Miyagi's theory (2006). Through this method it was possible to observe the variables of the event, being called arrival and departure (MARCELINO et al., 2018).

Through the results presented, the need for queue management was highlighted, through simulation, it is possible to identify failures and resolve them in order to guarantee the improvement of operations and services (FITZSIMMONS; FITZSIMMONS, 2006).

When interacting with the Arena software as well as during data insertion, it was also possible to conclude that the tool is easy to understand and useful. (FREITAS FILHO, 2008). This conclusion contrasts the difficulties exposed by Santos (1999).

\section{CONCLUSIONS}

From this research it was possible to observe the concept and discrete simulation application and its application to queue management. It is also noted that the simulation can be applied to the most diverse scenarios, productive, business, routine and so on. The work also points out that the discrete simulation is not a substitute for human work, but is linked to it, as it involves data analysis and interpretation, among its many advantages it saves time, financial investments and even reproduces the study scenario close to reality.

It is observed that the problem presented in the case study, was found through data collection and interview, with that the environment could be simulated, through the Arena software, which in its operation, simulated the entry and exit of customers, generated satisfactory statistical and probabilistic results. By observing the aforementioned processes and results, it is possible to conclude that if the addition of 2 to 3 cashiers is applied, the time spent by customers in the queue will be optimized by $88.23 \%$. The average queue size will be reduced by $87.68 \%$. The average use of the attendant is reduced by $5.17 \%$.

It is important to note that the focus of the research is discrete simulation, to solve the inefficiency of queue management, in a supermarket, that is, the cost of including one more employee in the execution of the cashier's task was not taken into account, as well as 
DOI: 10.14807/ijmp.v11i5.1296

economical solutions for the presented solution were not evaluated. It is believed that through future studies, such points can be considered as well as considering the possibility of increasing the amount of sample guaranteeing an effective complexity for solving problems.

\section{REFERENCES}

ANTUNES, M. G. P.; SANTOS, J. R. T. (2019) Aplicação da modelagem e simulação computacional como ferramenta de otimização de processos do setor de pós-venda em uma empresa de prestação de serviços. Brazilian Journal of Development, v. 5, n. 7, p. 79317943.

BANKS, J.; CARSON, J. S.; NELSON, B. L.; NICOL, D. M. (2010) Discrete-event system simulation. 5 ed. New Jersey: Prentice Hall.

CAMPOS, C. C. S.; ENCARNAÇÃO, E.; SILVA, A. M. (2019) Simulação discreta aplicada à distribuição da alimentação escolar: Estudo de caso em uma escola pública. South

American Development Society Journal, [S.l.], v. 5, n. 14, p. 290.

CARVALHO, Filipe Silva et al. Otimização de processo utilizando programação linear: estudo de caso em um salão de beleza. (2020) South American Development Society Journal, [S.l.], v. 5, n. 15, p. 438.

CHWIF, L.; MEDINA, A. C. (2014) Modelagem e Simulação de eventos discretos: Teorias e Aplicações, 4 ed. São Paulo: Elsevier.

CLEMENTINO, M. R. et al. (2018) Discrete simulation applied to a gas appliance company. Independent Journal of Management \& Production, v. 9, n. 5, p. 699-715.

CORDEIRO, J. C. A. et al. (2017) Estratégias híbridas de produção em sistemas make to stock (MTS) e make to order (MTO) com otimização multiobjetivo. Produto \& Produção, v. 18, n. 4.

COSTA, L. S. et al. (2017) Discrete simulation applied to the production process of electronic components. Independent Journal of Management \& Production, v. 8, n. 5, p. 596-613.

COUTINHO, L.; FERRAZ, J. C. (1995) Estudo da competitividade da indústria brasileira, 3 ed. São Paulo: UNICAMP.

DASSAN, E. F. et al. (2016) Otimização multiobjetivo em uma Linha de Produção de Placas Eletrônicas de uma Pequena Empresa. Revista ESPACIOS, Vol. 37, n. 26.

DIEHL, A. A. (2004) Pesquisa em ciências sociais aplicadas: métodos e técnicas. São Paulo: Prentice Hall.

DUARTE, R. N. (2003) Simulação Computacional: Análise de uma célula de manufatura em lotes do setor de autopeças. Dissertação de mestrado em Engenharia de Produção. UNIFEI. Itajubá, Minas Gerais.

FITZSIMMONS, J. A.; FITZSIMMONS, M. J. (2006) Service management: Operations, strategy, and information technology, 5 ed. New York: McGraw Hill.

FREITAS FILHO, P. J. (2008) Introdução à Modelagem Simulação de Sistemas com Aplicações em Arena, 2 ed. São Paulo: Visual Books. 
GOMES, J. et al. (2019) Programação linear aplicada à mobilidade urbana: análise do trajeto da residência à escola de estudantes universitários. Revista Eniac Pesquisa, v. 8, n. 2, p. 280-297.

HARREL, C.; GHOSH, B. K.; BOWDEN, R. O. (2004) Simulation using Promodel, 2 ed. Boston: MacGrawhill.

HILLIER, F. S.; LIEBERMAN, G. J. (2012) Introdução à pesquisa operacional, 9 ed. São Paulo: AMGH.

MARCELINO, A. R. A.; COSTA, D. C.; MARTINS, M. H.; ALMEIDA, M. A. F. (2018)

Simulação discreta em 3D de uma linha de embalagem carretéis MIG/MAG usando software símio. PUC, Brazilian Apillied Science Review, Minas Gerais, n. 4, p. 1159.

MARINS, F. A. S. (2011) Introdução à Pesquisa Operacional. São Paulo: Cultura Acadêmica: Universidade Estadual Paulista.

MIRANDA, L. S. A. P.; ALMEIDA, J. F. F.; PINTO, L. R. (2017) Uso da simulação para o dimensionamento de frota de caminhões de uma transportadora. XLIX Simpósio Brasileiro de Pesquisa Operacional. Blumenau-SC.

MIYAGI, P. E. (2006) Introdução a Simulação Discreta. Departamento de Engenharia Mecatrônica e de Sistemas Mecânicos. São Paulo: USP

MORAES, D. G., FERREIRA, C. V., SILVA, A. M. (2019). Otimização da produção utilizando Programação Linear: estudo de caso em uma indústria de esquadrias de alumínio. Refas-Revista Fatec Zona Sul, 5(4), 26-37.

MOREIRA, D. A. (2007) Pesquisa Operacional - Curso Introdutório. São Paulo: Editora Thomson.

OLIVEIRA, M. L. M.; MIRANDA, R. C.; MONTEVECHI, J. A. B. (2009)

Desenvolvimento de um projeto de simulação a eventos discretos em uma célula de controle de qualidade de uma empresa de alta tecnologia. Simpósio Brasileiro de Pesquisa Operacional - XLII-SBPO, Bento Gonçalves-RS, p. 2713-2723.

PEÑA, F. C.; SANTOS, J. V. C. (2018) Aplicação do método de simulação de monte carlo para redução de tempo de espera de passageiros de transportes verticais - elevadores. In: $\mathrm{L}$

SIMPÓSIO BRASILEIRO DE PESQUISA OPERACIONAL, Rio de Janeiro. Available: https:/proceedings.science/sbpo/papers/aplicacao-do-metodo-de-simulacao-de-monte-carlopara-reducao-de-tempo-de-espera-de-passageiros-de-transportes-verticais. Access: 6th aug. 2019.

PESSANHA, A. M. B.; ROCHA FILHO, S. M. D.; MELO, N. A. F. (2011) Estudo da aplicação do software arena em um contrato de prestação de serviço de manutenção de instrumentação. Revista: Perspectivas Online Ciências Exatas e Engenharia, n. 2. p. 1-24.

PRADO, D. (2014) Teoria das Filas e da Simulação. 5 ed. São Paulo: Nova Falconi.

SANTOS, L. M.; DANTAS, M. J. P. (2018) Ensino de simulação: avaliação do impacto da escolha das distribuições de probabilidade na ausência de dados. Brazilian Applied Science Review, v. 2, n. 1, p. 157-169.

SANTOS, M. P. (1999) Introdução à simulação discreta. Rio de Janeiro: UERJ.

SASAKI, N. K. (2007) Simulação de sistemas de comunicação optica baseada em simulação a eventos discretos. Dissertation (Master in Eletric Engineering). Campinas, SP: UNICAMP, Available: http:// http://repositorio.unicamp.br/handle/REPOSIP/258932.

Access: 6th aug. 2019. 
SILVA et al. (2018). Otimização da produção em sistemas puxados: análise em uma fábrica de móveis de aço. Revista Científica Hermes, 20, 62-85.

SILVA, E. L.; MENEZES, E. M. (2005) Metodologia de Pesquisa e Elaboração da Dissertação, 4 ed. Florianópolis: Revista Atual.

SILVA, E. M. D.; SILVA, E. M. D.; GONÇALVES, V.; MUROLO, A. C. (2010) Pesquisa Operacional, 4 ed. São Paulo: Gen Atlas.

VIEIRA, G. E. (2006) Uma revisão sobre a aplicação de simulação computacional em processos industriais. Simpósio de Engenharia de Produção, XIII, Bauru, Anais, p. 1-10.

VERGARA, B. M.; ANDRADE, G. S.; OLIVEIRA, K. J. J.; SANTOS, R. S.; SANTOS, Y. B. I. (2019) Aplicação da teoria das filas em uma rede de cinemas. Brazilian Journal of Business, v. 1, n. 2, p. 533-545.

YIN, R. K. (2015) Estudo de Caso Planejamento e métodos, 5 ed. Porto Alegre: Bookman. ZANELLI, J. C. (2002) Pesquisa qualitativa em estudos da gestão de pessoas. Estudos de Psicologia (Natal), v. 7, n. spe, p. 79-88. 